\title{
PENERAPAN CONCEPT LEARNING MODEL PADA PEMBELAJARAN PENDIDIKAN PANCASILA DAN KEWARGANEGARAAN DI SMA PGRI KABUPATEN CIANJUR
}

\author{
Iyep Candra Hermawan ${ }^{1}$, Dina Indriyani ${ }^{2}$, Heri Munadi ${ }_{2}^{3}$ \\ iyepcandra59@yahoo.com ${ }^{1}$, dinaindriyani08@gmail.com ${ }^{2}$
}

\begin{abstract}
Abstrak: Penelitian ini dimaksudkan untuk mengungkapkan penerapan concept learning model dan esensinya dalam pembelajaran PPKn di persekolahan. Peningkatan kualitas pembelajaran ditentukan oleh peranan guru dalam menerapkan pilihan model pembelajaran. Hasil penelitian menunjukkan bahwa penerapan concept learning model berpengaruh secara signifikan terhadap peningkatan kualitas pembelajaran PPKn. Kualitas pembelajaran dibuktikan baik secara substantif dalam pemahaman konsep dan generaliasi, maupun secara psikologis dalam pengembangan kepribadian dan keterampilan terkait dengan kemampuan mendeskripsikan, menganalisis, dan mempresentasikan bahan ajar Pendidikan Pancasila dan Kewarganegaraan (PPKn) di SMA PGRI Kabupaten Cianjur. Respon peserta didik bahwa dalam pembelajaran PPKn dirasakan tidak jenuh dan membosankan, keterlibatan secara aktif sehingga pembelajaran dirasakan amat komunikatif dan lebih familier, kemampuan peserta didik dalam mengungkapkan pendapat, serta pemahaman konsep dan memberikan contoh yang aktual dan kontroversial.
\end{abstract}

Kata Kunci: concept learning model, pembelajaran PKn

\section{PENDAHULUAN}

Pembelajaran yang efektif
memiliki peranan penting dalam
menghidupkan suasana belajar dan proses
pembelajaran. Melalui pembelajaran
efektif dapat mengembangkan potensi
peserta didik untuk mengungkapkan
peranan dan keikutsertaannya dalam
proses pencapaian tujuan pendidikan. Sehingga diharapkan peserta didik memiliki kemampuan untuk mengembangkan potensi dirinya dalam kepribadian, kecerdasan dan keterampilan.

Dalam upaya meningkatkan kualitas pembelajaran yang mengarahkan pada pencapaian tujuan pendidikan, maka keprofesionalan guru dituntut memiliki kemampuan akademis dalam pembelajaran di tingkat persekolahan. Karakteristik profesionalisme dicirikan oleh syarat-syarat formal seperti yang ditegaskan pada peraturan perundangundangan. Namun, kenyataan menunjukkan bahwa dalam pembelajaran di sekolah guru masih sering terjebak pada kegiatan rutinitas dan belum terpanggil dalam pengembangan akademik baik secara substansial maupun metodologis. Padahal guru yang profesional selalu dituntut dalam pengembangan inovasi pembelajaran.

Inovasi dan kreativitas dalam pembelajaran dapat diterapkan melalui berbagai pilihan model pembelajaran. Sebagai salah satu pengembangan yang dapat dilakukan oleh guru PPKn dalam proses pembelajaran di persekolahan adalah dengan menerapkan model pembelajaran konsep (concept learning model). Melalui model pembelajaran

1,2,3 Universitas Suryakancana 
konsep sehingga diharapkan peserta didik dapat mengembangkan potensinya dalam kaitan dengan keberanian mengemukakan pendapat, merumuskan konsep dan generalisasi, mempresentasikan dan mendiskusikannya.

\section{LANDASAN TEORITIK}

Pengembangan Model Pembelajaran PPKn

Dalam kaitannya dengan mengajar, guru seharusnya dapat mengembangkan berbagai alternatif model pembelajaran (model mengajar). Melalui penerapan model pembelajaran

diharapkan dapat meningkatkan kemampuan guru, mengenal keberadaan siswa, dan menciptakan lingkungan lebih bervariasi bagi kepentingan belajar siswa. Azis Wahab (2007: 52) menyebutnya dengan -model mengajar\| yaitu sebuah perencanaan pengajaran yang menggambarkan proses yang ditempuh pada proses belajar mengajar agar dicapai perubahan spesifik pada perilaku siswa seperti yang diharapkan. Dengan pengembangan model mengajar diharapkan dapat menciptakan suasana belajar-mengajar lebih hidup, menarik, dan menyenangkan. Melalui pengembangan model mengajar kepada guru dituntut untuk mengembangan inovasi pembelajaran dan kepada siswa dituntut untuk mengembangkan potensi dan kreativitasnya.

Bruce Joyce dkk (2009: 31) telah mengelompokkan model-model pengajaran ke dalam empat kelompok pengajaran yang para -anggotall-nya memiliki orientasi pada (sikap) manusia dan bagaimana mereka belajar.
Kelompok-kelompok tersebut adalah: (1) Kelompok Model Pengajaran Memproses Informasi (the information-processing family); (2)Kelompok Model Pengajaran Sosial (the social family); (3) Kelompok Model Pengajaran Personal (the personal family); (4) Kelompok Model Pengajaran Sistem Perilaku (the behavioral systems family).

Pengembangan

Model

pembelajaran dimaksudkan sebagai suatu upaya menciptakan kondisi belajar mengajar yang dialogis, efektif, dan produktif. Melalui model pembelajaran sehingga diharapkan siswa memperoleh informasi, gagasan, skill, nilai, cara

berpikir, dan kemampuan mengekspresikan diri sebagai bagian daripada belajar. Keberhasilan dalam pembelajaran tidak semata diukur dari guru dalam kemampuannya menyajikan materi. Menurut Bruce Joyce (2009: 7) bahwa guru yang sukses bukan sekadar penyaji yang kharismatik dan persuasif. Tetapi lebih jauh, guru yang sukses adalah mereka yang mampu melibatkan para siswa dalam tugas-tugas yang sarat muatan kognitif dan sosial, dan mengajari mereka bagaimana mengerjakan tugastugas tersebut secara produktif.

Penerapan model mengajar di sekolah seharusnya tidak menjadi beban bagi guru, tetapi sesungguhnya dapat membantu guru untuk memberikan kemudahan dan keleluasaan dalam menciptakan lingkungan pembelajaran yang efektif dan menyenangkan. Pilihan dan penentuan model mengajar akan tergantung dari bagaimana kemampuan gurunya, penyesuaian dengan topik bahasannya, tujuan yang dirumuskannya, 
pengkondisian peserta didiknya, serta langkah-langkah yang harus disiapkannya. Karenanya, Azis Wahab (2007: 58) menyebutkan beberapa model mengajar yang memungkinkan dapat diterapkan dalam lingkungan persekolahan, yaitu: (1) Model yang Berorientasi pada Interaksi Sosial; (2) Model yang Berorientasi pada Pemrosesan Informasi; dan (3) Model yang Berorientasi pada Pribadi. Model yang pertama, menekankan pentingnya hubungan sosial yang berkembang dalam proses interaksi sosial di antara individu.

Pengembangan interaksi sosial menjadi tuntutan dan tujuan dalam pembelajaran. Model ini dimaksudkan sebagai upaya memperbaiki masyarakat dengan menciptakan dan memperbaiki hubungan interpersonal melalui prosedur demokratis. Model ini berarti mengajarkan dan melatihkan kepada individu dalam mengembangkan dan

membangun budaya demokratis. Diantaranya yang tergolong pada model ini adalah Model Investigasi Kelompok yang dikembangkan oleh John Dewey dan Herbert A. Thelen; serta Model Inkuiri Sosial yang dikembangkan Byron Massialas dan Benyamin Cox.

Model yang kedua, menekankan pada bagaimana cara siswa memproses informasi. Tujuan dari model ini yaitu membantu siswa dalam mengembangkan cara-cara memproses informasi yang diperoleh dari lingkungannya. Kemampuan memproses dan mengolah informasi dengan pendekatan yang berbeda, yaitu berpikir induktif dan deduktif. Berdasarkan pendekatan tersebut, siswa diajarkan dan dilatihkan dalam mengembangkan kemampuan berpikir, yaitu mengamati masalah, mengembangkan konsep dan generalisasi, serta mempresentasikan hasil. Yang termasuk dalam model ini yaitu, Model Mengajar Induktif yang dikembangkan oleh Hilda Taba (1979); Model Mengajar Pemrolehan Konsep yang dikembangkan Jerome S. Bruner, Jacqueline Goodrow dan George Austin tahun 1956; Model

Mengajar Pengembangan yang dikembangkan oleh Piaget; Model Menyusun yang Lebih Lanjut yang dikembangkan oleh David Ausubel.

Model yang ketiga, yaitu Model yang Berorientasi pada Pribadi. Modelmodel yang termasuk dalam kelompok ini lebih memusatkan perhatian pada individu dan kebutuhannya. Melalui model mengajar ini, membantu individu mengembangkan kemampuannya dalam memahami sifat-sifat pribadi, menyelami masalah individu dan dalam hubungannya dengan lingkungan masyarakat, serta dalam upaya meningkatkan produktivitasnya. Yang termasuk dalam kategori model ini ialah Model Mengajar Bebas yang dikembangkan Carl Rogers;

Model Pertemuan Kelas yang dikembangkan Robert Glaser.

Dalam memperluas wawasan pengetahuan dan disiplin ilmu pengetahuan, peserta didik harus lebih diarahkan dalam pengenalan konsep, generalisasi, dan teori. Istilah -konsep\| adalah gagasan yang merujuk pada sebuah kelompok atau kategori di mana semua anggotanya sama-sama memiliki beberapa karakteristik umum. Azis Wahab (2007) mendefinisikan konsep sebagai kumpulan pengertian abstrak yang berkaitan dengan simbol untuk kelas dari suatu benda, 
kejadian atau gagasan. Berbagai contoh untuk penyebutan konsep seperti masyarakat, nasionalisme, kesejahteraan sosial, dan lain-lain. Sedangkan istilah

- generalisasill adalah pernyataanpernyataan mengenai pola-pola yang ada dalam dunia, baik pola-pola yang memiliki hubungan korelasional maupun hubungan kausal. Istilah lain yang digunakan untuk merujuk pola-pola ini adalah -aturan, prinsip, atau hukumll. Sebutan generalisasi terdiri atas beberapa konsep misalnya konsep —negara, keadilan, dan keselamatan\|. Sebagai contoh generalisasi yang dirumuskan oleh Tim Civic Education Research Project yaitu -Manusia membuat organisasi negara untuk memperoleh keadilan,

keselamatan, dan kesejahteraan\| (Somantri, 2001: 288).

James A. Banks (1985) yang dikutip Azis Wahab (2007: 131) mengemukakan beberapa konsep kunci Ilmu Pengetahuan Sosial (IPS) atau Studi Sosial seperti ditunjukkan pada tabel 2 berikut di bawah ini.

Tabel 1

Konsep Kunci IPS/Social Studies (SS)

\begin{tabular}{|c|c|c|c|c|c|}
\hline No. & Disiplin Ilmu & Konsep & No. & $\begin{array}{c}\text { Disiplin } \\
\text { Ilmu }\end{array}$ & Konsep \\
\hline 1. & History & $\begin{array}{ll}\text { Change, } & \text { leadership, } \\
\text { conflict, } & \text { cooperaton, } \\
\text { nationalism, } & \text { exploration, } \\
\text { relativism, historical }\end{array}$ & 4. & $\begin{array}{l}\text { Political } \\
\text { Science }\end{array}$ & $\begin{array}{l}\text { Power, social control, } \\
\text { state, interest group, } \\
\text { structure of a city, } \\
\text { political socialization, } \\
\text { political participation }\end{array}$ \\
\hline 2. & Sociology & $\begin{array}{l}\text { Socialization, roles, norms } \\
\text { and sanction, values, } \\
\text { social movement, society }\end{array}$ & 5. & Economics & $\begin{array}{l}\text { Scarcity, production, } \\
\text { interdependence, } \\
\text { specialization and } \\
\text { division of labour, } \\
\text { voluntary exchange }\end{array}$ \\
\hline 3. & Antropology & $\begin{array}{l}\text { Culture, } \\
\text { tradition, acculturation, } \\
\text { ethnocentrism, cultural, } \\
\text { rite of passage }\end{array}$ & 6. & Geography & $\begin{array}{l}\text { Location } \\
\text { internal, urban spatial } \\
\text { pattern } \\
\text { cultural internal, } \\
\text { environmental diffusion, } \\
\text { perception }\end{array}$ \\
\hline
\end{tabular}

(Sumber: Diadaptasi dari Wahab (2007: 131)

Beberapa contoh generalisasi yang menggambarkan hubungan sebab-akibat seperti dikemukakan Jacobsen dkk (2009: 102) adalah sebagai berikut.

- Merokok dapat menyebabkan kanker.

- Kekurangan sinar matahari dapat menyebabkan tanaman tumbuh tinggi.
- Panas dapat membuat molekul berpindah lebih cepat.

Sedangkan generalisasi lain yang menggambarkan sebuah hubungan antar beberapa konsep di mana suatu keadaan biasanya diikuti atau dihubungkan dengan keadaan lain. Sebagai contoh berikut di bawah ini. 
- Waktu yang dihabiskan untuk mempelajari sebuah materi pelajaran berhubungan dengan prestasi yang nantinya akan mampu dicapai pada saat itu.

- Keluarga yang berstatus ekonomi rendah memiliki anak lebih banyak dibanding keluarga yang berstatus ekonomi lebih tinggi.

- Masalah manajemen lebih banyak terjadi saat siswa bekerja secara individual dibanding saat mereka bekerja dalam bentuk kelompok. Menurut Numan Somantri (2001:

287) bahwa generalisasi harus ditandai dengan: (a) dapat diaplikasikan secara universal pada tingkatan abstraksi yang relevan pada masa lampau dan juga harus menyangkut berbagai jenis kegiatan; (b) pernyataan pendapat yang dapat diuji

kebenarannya. Numan Somantri memberikan contoh tentang konsep dasar dan generalisasi, yaitu - Hidup yang lebih baik dan menyenangkan akan dapat tumbuh apabila manusia:

a. Memelihara alam sekitarnya.

b. Kerja sama dan saling tukar menukar jasa dan hasil karyanya.

c. Mengorganisasikan diri dengan tertibll.

Dari gambaran tersebut di atas, peserta didik harus dimotivasi dan dikembangkan potensinya dalam mengenal beberapa konsep dan menjelaskannya serta dapat menuangkan gagasan dalam kemampuan merumuskan generalisasi. Pengembangan konsep dan perumusan generalisasi dapat dilatihkan kepada peserta didik yang dihubungkan dengan kehidupan nyata (the real life) dan aktual yang dihadapi dalam lingkungan keluarga, sekolah, masyarakat, dan bangsa.

\section{Penerapan Model Pembelajaran} Konsep Pada Pembelajaran PPKn

Batasan tentang -cooperative learning $\|$ sebagaimana dikemukakan Bern dan Erickson (2001) yaitu merupakan strategi pembelajaran yang mengorganisir pembelajaran dengan menggunakan kelompok belajar kecil di mana siswa bekerja bersama untuk mencapai tujuan pembelajaran. Melalui strategi pembelajaran kooperatif ini di mana siswa belajar dan bekerja dalam kelompokkelompok kecil secara kolaboratif yang anggotanya terdiri dari 2 sampai 5 orang, dengan struktur kelompoknya yang bersifat heterogen (Komalasari, 2010: 62).

Pembelajaran kooperatif yang dikembangkan Slavin (2010: 11) bersifat Pembelajaran Tim Siswa (PTS). Strategi pembelajaran kooperatif dapat diaplikasikan pada sebagian besar mata pelajaran dan tingkat kelas.

Dalam perkembangannya Model Pembelajaran Kooperatif melahirkan berbagai metode dan teknik yang bervariasi. Komalasari (2010: 62) mengemukakan model tersebut meliputi kepala bernomor (Numbered Heads Together), skrip kooperatif (Cooperative Script), tim siswa kelompok prestasi (Student Teams Achievement Division), berpikir berpasangan berbagi (Think Pair and Share), model Jigsaw, melempar bola salju (Snowball Throwing), Tim TGT (Team Games Tournament), kooperatif terpadu membaca dan menulis (Cooperative Integrated Reading and Composition), dua tinggal dua tamu (Two Stay Two Stray). 
Pembelajaran kooperatif pada pengembangan karakter maupun pencapaian akademis, Thomas Lickona (2013: 244) menyebutkan adanya delapan macam format kooperatif; dan guru hendaknya dapat memanfaatkan berbagai macam format kooperatif tersebut. Delapan macam pembelajaran kooperatif tersebut, yaitu: (1) pasangan belajar (learning partner); (2) pembagian kluster tempat duduk kelompok (cluster group seating); (3) pembelajaran tim (student team learning); (4) pembelajaran jigsaw (jigsaw learning); (5) ujian kelompok (team testing); (6) proyek-proyek kelompok kecil (small-group project); (7) persaingan tim (team competition); dan (8) proyek kelas (whole-class project).

\section{Pembelajarankooperatif}

merupakan gerakan pendidikan yang dipandang paling cepat berkembang karena model pembelajaran ini memberikan manfaat secara efektif. Melalui pembelajaran kooperatif dapat mengajarkan nilai-nilai dan pengetahuan akademis secara bersamaan. Thomas Lickona (2013: 240) mengemukakan manfaat khusus dari pembelajaran kooperatif adalah sebagai berikut: (1) Pembelajaran kooperatif mengajarkan nilai kerjasama; (2) Pembelajaran kooperatif dapat membangun komunitas di dalam kelas; (3) Pembelajaran kooperatif mengajarkan keterampilan dasar; (4) Pembelajaran kooperatif dapat meningkatkan pencapaian akademis, penghargaan diri, dan sikap terhadap sekolah; (5) Pembelajaran kooperatif menawarkan sebuah alternatif untuk pengelompokan siswa; dan (6) Pembelajaran kooperatif berpotensi mengurangi aspek-aspek negatif persaingan.

\section{DESKRIPSI DAN ANALISIS DATA Deskripsi Data}

Deskripsi data diperoleh berdasarkan catatan lapangan dari sejumlah informasi pada sebelum dan saat berlangsungnya kegiatan pembelajaran di kelas. Kegiatan proses pembelajaran

berlangsung selama sepuluh kali pertemuan sejak tanggal 9 Agustus 2018 sampai dengan 17 September 2018 pada kelas X IPA-1, kelas X IPA-2 dan kelas X IPS di SMA PGRI Kabupaten Cianjur.

Sebelum dilakukan kegiatan pembelajaran, terlebih dahulu peneliti bersama dengan guru PPKn melakukan pembicaraan, merumuskan permasalahan dan memperoleh kesepakatan. Setelah dilakukan dialog dan diskusi, beberapa hal yang telah dirumuskan yaitu: (1) merumuskan silabus dan RPP; (2) menentukan Kompetensi Dasar (KD) dan bahan ajar; (3) menyiapkan fasilitas untuk kepentingan pembelajaran; (4) melakukan observasi pada kelas yang dijadikan objek penelitian; dan (5) melaksanakan kegiatan pembelajaran pada kelas-kelas yang telah ditentukan.

Terdapat dua Kompetensi Dasar (KD) yang dilakukan dalam pembelajaran, yaitu pertama, KD tentang -Ketentuan UUD NRI Tahun 1945 dalam Kehidupan Berbangsa dan Bernegarall dan kedua, KD tentang - Kewenangan Lembaga-lembaga Negara menurut UUD NRI Tahun 1945॥. Pada kompetensi dasar pertama mengupas materi bahasan tentang -Wilayah Negara Kesatuan Republik Indonesia (NKRI)\|. Pembelajaran menggunakan metode 
pembelajaran konsep. Adapun langkah pembelajaran yang dilakukan adalah: (a) Siswa dibagi menjadi 5 kelompok untuk menemukan konsep pada pokok bahasan yang terdapat dalam buku sumber; (b) Setiap kelompok menuliskan temuan kelompoknya dalam suatu lembar kerja siswa untuk kemudian dipresentasikan kepada kelompok lainnya; (c) Pada akhir pembelajaran, guru mengadakan refleksi dengan melontarkan beberapa pertanyaan seputar materi yang didiskusikan.

Sedangkan pada kompetensi dasar kedua, yaitu -Kewenangan Lembagalembaga Negara menurut UUD NRI Tahun 1945\| menyoroti materi bahasan tentang - Suprastruktur dan Infrastruktur Sistem Politik Indonesiall. Pembelajaran menggunakan metode pembelajaran kartu konsep. Adapun langkah pembelajaran yang dilakukan adalah: (a) Siswa diberikan kesempatan untuk membaca buku sumber selama 15 menit; (b) Siswa dikelompokkan, yang terdiri dari 5 kelompok untuk melakukan diskusi; (c) Setiap kelompok diberikan kartu konsep untuk didiskusikan bersama dan kemudian hasil diskusi ditulis dalam kartu konsep yang disediakan dan jika sudah selesai secara bergiliran setiap kelompok mempresentasikan hasil diskusinya; (d)

Pada akhir pembelajaran, guru mengadakan post test untuk mengetahui tingkat pemahaman siswa terhadap materi yang disampaikan.

\section{Analisis Data}

Mengingat banyaknya manfaat yang dapat dirasakan dari pembelajaran kooperatif, maka dari itu variasi terhadap model pembelajaran kooperatif harus senantiasa dikembangkan. Pada kesempatan kali ini pengembangan pembelajaran kooperatif dilakukan dengan menerapkan model pembelajaran konsep. Pada model pembelajaran konsep ini, siswa diajak untuk menemukan beberapa konsep yang berkenaan atau terdapat dalam setiap materi pelajaran yang disampaikan. Siswa diajak untuk menggali konsep-konsep yang terdapat dalam materi pelajaran untuk kemudian siswa mencoba mendefinisikan setiap konsep yang ditemukan sehingga siswa mampu memberikan deskripsi terhadap

konsep yang ditemukan. Dengan penemuan konsep tersebut diharapkan siswa menjadi lebih mampu memahami konsep temuannya sehingga materi dapat tersampaikan dengan baik.

Adapun langkah-langkah dalam pembelajaran konsep yang diterapkan pada pembelajaran dengan materi Wilayah Negara Kesatuan Republik Indonesia adalah sebagai berikut:

(1) Siswa dikelompokkan dalam kelompok yang terdiri dari 3-4 orang. Pembagian kelompok dilakukan secara random dengan harapan dapat lebih melatih kerja rasa siswa satu sama lain;

(2) Setiap kelompok diberikan beberapa sumber belajar yang berbeda untuk kemudian dibaca. Sumber belajar yang digunakan adalah beberapa artikel yang diambil dari jurnal-jurnal yang dianggap relevan dengan materi ajar.

Sumber belajar yang digunakan diberikan berbeda dengan harapan dapat lebih 
memperluas wawasan siswa karena pada akhir pembelajaran siswa akan memperoleh keseluruhan sumber belajar yang digunakan.;

(3) Dari sumber belajar yang telah diberikan, kelompok siswa tersebut dipersilakan untuk mencari konsep yang terdapat pada sumber belajar. Siswa mencatat hasil temuan konsepnya dan kemudian menuliskan deskripsi dari setiap konsep hasil temuannya. Setelah membaca sumber belajar, siswa diminta untuk mencatat konsep-konsep yangditemukandan mendeskripsikankonsep tersebut. Dalam mendeskripsikan konsep yang ditemukannyasiswa dipersilakan memanfaatkan media internet untuk lebih memahami konsep tersebut;

(4) Setiap kelompok memaparkan hasil temuannya di depan kelas dan kelompok yang lainnya memberikan masukan terhadap hasil temuan konsep dari kelompok yang presentasi. Pada tahap ini siswa memaparkan hasil temuannya. Kelompok yang lain diberikan kesempatan untuk memberikanmasukan terhadap konsep temuannya.

Berdasarkan hasil presentasi yang dilakukan oleh siswa pada akhir pembelajaran, siswa sudah mampu menemukan konsep-konsep yang ada dalam sumber belajar yang diberikan, misalnya siswa dapat menemukan konsep wilayah, konsep negara kesatuan, konsep wilayah darat, konsep wilayah laut, konsep wilayah udara, dan lain-lain. Tidak hanya sekedar menemukan, tetapi siswa juga mampu mendeskripsikan konsep tersebut secara lebih terperinci sehingga tingkat pemahaman siswa terhadap materi ajar Wilayah Negara Kesatuan Republik Indonesia.

Pada pembelajaran kedua, peneliti menerapkan modifikasi pembelajaran konsep dengan menggunakan kartu

konsep. Adapun langkah-langkah pembelajarannya adalah sebagai berikut:

(1) Siswa diberikan kesempatan untuk membaca buku sumber selama 15 menit. Buku sumber yang

digunakan sebagai sumber utama/inti adalah buku sumber yang memang sudah disediakan oleh sekolah yang merupakan buku pegangan yang diterbitkan oleh Kementerian Pendidikan dan Kebudayaan Indonesia. Disamping buku sumber utama, siswa juga diperbolehkan untuk membaca buku sumber yang berbeda;

(2) Siswa dikelompokkan, yang terdiri dari10kelompokuntuk melakukan diskusi. Pengelompokkan dilakukan secara radom;

(3) Setiap kelompok diberikan kartu konsep untuk didiskusikan bersama dan kemudian hasil diskusi ditulis dalam kartu konsep yang disediakan dan jika sudah selesai secara bergiliran setiap 
kelompok mempresentasikan hasil diskusinya. Guru memberikan masing-masing 1 kartu konsep kepada setiap kelompok untuk kemudian didiskusikan bersama kelompoknya. Kartu konsep yang disiapkan antara lain, sistem politik, ciri sistem politik, infrastruktur politik, suprastruktur politik, macam-macam suprasutruktur politi, partai politik, tugas dan fungsi partai politik, kelompok penekan, kelompok kepentingan, dan media komunikasi politik;

(4) Pada akhir pembelajaran, guru mengadakan post test untuk mengetahui tingkat pemahaman siswa terhadap materi yang disampaikan.Post-testyang dilakukan adalah dengan memberikan pertanyaan sesuai dengan kartu konsep yang telah diberikan. Dari post test tersebut diperoleh hasil ternyata siswa tidak mengalami kesulitan untuk menjawab soal-soal yang tersedia. Siswa dapat mendeskripsikan dengan baik terkait konsep yang dipertanyakan. Kondisi ini menunjukkan kualitas pemahaman siswa terhadap materi sangat baik.

Pembelajaran konsep ini, peneliti coba terapkan pada pembelajaran PPKn di kelas X SMA PGRI Cianjur dengan mengambil materi tentang -Ketentuan UUD Negara Republik Indonesia Tahun 1945 dalam Kehidupan Berbangsa dan Bernegarall dan -Kewenangan Lembagalembaga Negara menurut UUD NRI Tahun 1945\|. Dari hasil evaluasi terhadap proses pembelajaran dengan menerapkan pembelajaran konsep tersebut diperoleh temuan sebagai berikut:

(1) Siswa lebih termotivasi untuk belajar.Dikarenakan pembelajaran dilakukan dengan menggunakan model pembelajaran yang relatif baru bagi siswa sehingga siswa antusias dalam proses pembelajaran.

(2) Siswa merasa lebih mudah memahami materi. Dikarenakan mereka yang menemukan sendiri konsep dan mendeskripsikannya sehingga materi lebih cepat dicerna oleh siswa.

(3) Tingkat pemahaman siswa terhadap materi ajar baik. Ketika diadakan evaluasi materi pada akhir pembelajaran dengan mencoba memberikan beberapa pertanyaan kepada siswa, siswa mampu menjawab pertanyaan yang diberikan dengan baik.

Berdasarkan hasil temuan tersebut dapat disimpulkan bahwa penerapan model pembelajaran konsep dalam pembelajaran PPKn di Kelas X SMA PGRI Cianjur memberikan dampak positif terhadap pembelajaran PPKn.

\section{KESIMPULAN}

Berdasarkan hasil penelitian tersebut di atas diperoleh kesimpulan sebagai berikut:

1. Pembelajaran konsep mampu memberikan nuansa atmosfer yang berbeda dalam pembelajaran 
PPKn. Mampu memberikan nuansa yang lebih menyegarkan dan menyenangkan dalam pembelajaran PPKn.

2. Pembelajaran konsep lebih efektif meningkatkankualitas pembelajran PPKn. Mampu meningkatkan pemahaman siswa terhadap materi ajar dan lebih efektif dalam pencapaian tujuan belajar.

3. Pembelajaran konsep dipandang lebih efektif karena keterlibatan siswa secara aktif. Siswa memiliki kemampuan merumuskan dan mengungkapkan konsep.

\section{DAFTAR PUSTAKA}

Budimansyah, Dasim \& Suryadi, Karim. 2008. PKN dan Masyarakat Multikultural.

Bandung: Prodi PKn, Sekolah Pascasarjana UPI.

Jacobsen, David A. dkk. 2009. Methods for Teaching; Metode-Metode Pengajaran Meningkatkan Belajar Siswa TK-SMA. Terjemahan. Yogyakarta: Pustaka Pelajar.

Joyce, Bruce dkk. 2009. Models of Teaching; Model-Model Pengajaran. Terjemahan. Yogyakarta: Pustaka Pelajar.

Komalasari, Kokom. 2010. Pembelajaran Kontekstual: Konsep dan Aplikasi. Bandung: Refika Aditama. Lickona, Thomas. 2013. Pendidikan Karakter. Terjemahan: Educating for Character. Bandung: Nusa Media.

Mulyasa, E. 2003. Kurikulum Berbasis Kompetensi; Konsep, Karakteristik, dan Implementasi. Bandung: Remaja Rosdakarya.

Sapriya \& Winataputra, Udin S. 2004. Pendidikan Kewarganegaraan; Model Pengembangan Materi dan Pembelajaran. Bandung: Lab. PKn, Jurusan PKn-FPIPS UPI. Slavin, Robert E. 2010. Cooperative Learning; Teori, Riset dan Praktik. Terjemahan. Bandung: Nusa Media.

Solihatin, Etin \& Raharjo. 2007. Cooperative Learning; Analisis Model Pembelajaran IPS. Jakarta: Bumi Aksara.

Somantri, Muhamad Numan. 2001. Menggagas Pembaharuan Pendidikan IPS. Bandung: Remaja Rosdakarya.

Uno, Hamzah B. 2006. Perencanaan Pembelajaran. Jakarta: Bumi Aksara.

Uno, Hamzah B. 2007. Model Pembelajaran; Menciptakan Proses Belajar Mengajar yang Kreatif dan Efektif. Jakarta: Bumi Aksara.

Wahab, Abdul Azis. 2007. Metode dan Model-ModelMengajarIlmu Pengetahuan Sosial (IPS). Bandung: Alfabeta. 
